\title{
Reflexões sobre a velhice: identidades possíveis no processo de envelhecimento na contemporaneidade
}

\author{
Eloísa Pereira Barroso* \\ ORCID iD 0000-0002-6850-0234 \\ Universidade de Brasília, Departamento de História, Brasília, Brasil
}

\begin{abstract}
Resumo: Este artigo tem como objetivo pensar os processos de envelhecimento e as identidades dos velhos na contemporaneidade. Por meio da história oral entendemos a necessidade de uma escuta na qual os atos de fala revelados na voz da nossa narradora façam com que imaginários e representaçóes em que se alicerçam a compreensão e a definiçấo da velhice não sejam vistos como a reificaçâao de um pressuposto sobre o idoso. Como o envelhecer é um processo que se alicerça em uma definição inconcisa, as identidades atreladas ao processo de envelhecimento combinam um discurso reivindicador que transforma o processo de envelhecimento contemporâneo em uma experiência múltipla. Analisar a polifonia de significados do envelhecimento exige o trânsito entre categorias como grupo de nascimento, geração, classe social, terceira idade, entre outras, para se pensar questôes referentes aos processos de identificação do idoso como ser social, portador de experiências singulares.
\end{abstract}

Palavras-chave: Pessoa idosa. Memória. História oral. Narrativa. Identidade.

\section{Reflections on old age: possible identities in the aging process in contemporary times}

Abstract: This article aims to think about the aging processes and the identities of the elderly in contemporary times. Through Oral History we understand the need for a listening in which the speech acts revealed in the voice of our narrator make that imagery and representations on which the understanding and definition of old age are based are not seen as the reification of an assumption about the elderly. As aging is a process that is based on an uncertain definition, the identities linked to the aging process combine a claiming discourse that transforms the contemporary aging process into a multiple experience. Analyzing the polyphony of meanings of aging requires transit between categories such as birth group,

Professora Associada, diretora da Diretoria de Desenvolvimento Social (DDS) e Doutora em Sociologia pela Universidade de Brasília (UnB).E-mail: eloisabarroso@uol.com.br. 
generation, social class, old age, among others, to think about issues related to the identification of the elderly as a social being, with unique experiences.

Keywords: Elderly person. Memory. Oral History. Narrative. Identity.

Recentemente circulou na internet um vídeo interessante sobre como o envelhecimento é visto e percebido em solo brasileiro. Com mais de $500 \mathrm{mil}$ visualizaçóes, despertou debates intensos nas redes sociais, foi compartilhado em WhatsApp, Instagram, Facebook, acendeu reflexôes importantes e chamou a atenção para questôes relacionadas ao envelhecimento. A partir de um programa do humorista Fábio Porchat, a escritora, publicitária e influenciadora digital Cris Guerra, gravou um vídeo em sua conta do YouTube no qual se dirige ao humorista com a seguinte fala:

Porchat, envelhecer não é pros fracos, ainda mais em um país em que a palavra soa como um crime. A pessoa faz aniversário e já vai tentando arrumar uma identidade falsa. Não dá pra continuar incentivando esse preconceito. A longevidade, diga-se de passagem, é um dado muito recente da humanidade. (Guerra, 2021).

Essa fala prossegue em uma longa reflexão que tem como mote estabelecer uma crítica ao preconceito relacionado ao envelhecimento.

O fenômeno do envelhecimento náo pode ser estudado de forma isolada, pautada apenas em questôes de ordem biológica, pois questôes relacionadas ao grupo a que pertencem os idosos, ao local onde vivem e passaram a maior parte de suas histórias constituem-se em um conjunto de relaçóes de produçáo entrelaçadas que só são possíveis de serem compreendidas a partir de um olhar histórico, cultural e dialético. Objeto de interesse de muitos historiadores, os quais buscam uma definição do velho e do envelhecimento para além de fatores biológicos, estudos recentes trazem para o debate o contexto sócio-histórico em que o idoso encontra-se inserido, afinal o envelhecimento enquanto uma questáo-problema para a história precisa ser pensado a partir de uma historicidade, pois a velhice como um conjunto heterogêneo de vivências comporta práticas discursivas e/ou náo discursivas de objetivação que regulam as subjetividades.

Hoje é notório o crescimento do número de idosos no Brasil e no mundo. Tanto em terras brasileiras, como em muitos países em desenvolvimento, o aumento dessa população está cada vez mais acelerado, porém as mudanças nas condiçóes socioeconômicas ainda caminham a passos lentos. (Cervato; Derntl; Latorre; Marucci, 2005). Com a perspectiva desse aumento do número de idosos, o Brasil, segundo as projeçóes para 2025, atingirá a sexta populaçáo idosa do mundo em números absolutos (Kalache; Veras; Ramos, 1987). Tal perspectiva coloca para o país a necessidade de se pensar esse processo de envelhecimento em curso (Neri, 2007a). 
Definido como um processo sociovital multifacetado, o envelhecimento é condiçáo inerente aos seres vivos. Para os seres humanos, quando falamos em velhice estamos nos referindo ao resultado de processos de envelhecimento vividos e vivenciados por sujeitos em contextos sociais, políticos e individuais diversos (Lima et al., 2008; Neri, 2006). No livro A velhice, Simone de Beauvoir (1970, p. 247), ressalta que "[...] de todos os fenômenos contemporâneos, o menos contestável, o de marcha mais segura, o mais fácil de ser previsto com grande antecedência e talvez o mais pejado de consequência é o envelhecimento da população". Diante do aumento da expectativa de vida, se estabelece uma nova configuração socioeconômica. Novos serviços, novas profissóes, novos produtos emergem de forma considerável. Assim, a velhice começa a aparecer, torna-se visível, requerendo da sociedade programas e políticas públicas capazes de auxiliarem aqueles e aquelas que envelhecem.

Normalmente, o imaginário social sobre a velhice se institui a partir de representaçóes estabelecidas sob duas perspectivas: uma delas está associada àquela percebida pela influenciadora no vídeo do humorista Porchat, na qual o ser idoso é associado a um indivíduo infantilizado que vai perdendo sua autonomia na medida em que vai se aproximando dos 60 anos, mas, com o advento das novas tecnologias e a melhoria da ciência, que se tornou capaz de prolongar a vida, observa-se uma segunda perspectiva na qual o entendimento da velhice se edifica na máxima que é preciso "envelhecer melhor". Esse envelhecer melhor atrela-se a ações relacionadas à possibilidade de se consumir saúde e juventude, o que propicia qualidade de vida e passa a representar o sucesso no envelhecimento. Assim, cria-se um estilo de vida no qual a ocupaçáo do tempo livre passa a visar à necessidade de atender a um discurso pautado sempre na perspectiva da satisfação das necessidades produzidas em uma lógica na qual viver bem a velhice se impóe como produtividade constante, conduzida e garantida pela ciência.

Nesse contexto, um novo discurso se coloca para o idoso: envelhecer passa a ser considerado sob outras lógicas que náo aquela preconizada por muitos anos, que se pautava por uma espécie de imobilidade e ineficiência daquele que envelhece. Consumir um estilo de vida saudável e se movimentar incessantemente impóem uma outra experiência de ser idoso, pois mediante discursos especializados no assunto, envelhecer bem passa a significar a opção do idoso: consumir ou náo esse discurso. Diante dessa imposição discursiva, o que se coloca é o não encorajamento e o não reconhecimento da experiência singular de cada indivíduo, de maneira que se estabelece uma espécie de padrão prévio de condutas esperadas como forma de se envelhecer corretamente.

Para Baltes e Smith (2006), embora, segundo alguns dados, exista sim uma parcela significativa de idosos que apresenta nível elevado de comprometimento funcional, dependência e solidáo, hoje o envelhecer não pode ser sinônimo de doença e inatividade, é preciso considerar o processo de envelhecimento como um evento progressivo e multifatorial. Dessa maneira, urge pensar a velhice como mais uma experiência vivida ao longo da vida, porém, essa experiência não pode estar 
circunscrita a padrôes específicos e pré-determinados. Ao contrário, ela é heterogênea e vivenciada conforme diversas possibilidades dadas por questóes referentes tanto a questóes socioculturais como padróes socioeconômicos (Lima et al., 2008; Neri, 2003; Neri, 2007b; Neri; Yassuda; Cachioni, 2004). A velhice visibiliza e enuncia o corpo que envelhece como um problema social, de si e dos outros. Ela produz discursos que podem legitimar ou não o corpo velho, posto que a produçáo discursiva sobre o envelhecimento responde a determinadas urgências exigidas pelos contextos políticos, sociais, econômicos e culturais. Recentemente, as discussôes sobre a velhice têm se dado a partir de aspectos como o gênero, a sexualidade, a raça/etnia, a saúde mental, a mobilidade, a institucionalização, a sociabilidade, o trabalho e o consumo, pois considera-se que para pensar o envelhecimento é fundamental a análise de realidades localizadas em que as múltiplas diferenças articuladas constituem sujeitos históricos singulares.

A velhice e suas materialidades inscritas nas experiências despertam a nossa atenção porque, se tomados como marcas da modernidade, os materiais e os aspectos dos processos de envelhecimento são reveladores das contradiçóes da vida moderna. Os materiais culturais que fazem parte do universo da velhice nos interessam porque são fenômenos identitários, muitas vezes colocados à margem, que permitem conhecer a vida cotidiana e suas transformaçóes. Dessa maneira, pensar o envelhecer a partir das identidades requer um movimento dialético do pensamento, conforme sugere Walter Benjamin (2005) na sua teoria da modernidade. Um modo de compreender as questóes que se colocam para a modernidade é por esse movimento de pensar circunscrito a processos de aquietamento, momento em que o pensamento se imobiliza ante uma constelaçáo saturada de tensôes. $\mathrm{Na}$ perspectiva benjaminiana, o movimento do pensamento consiste em captar o tempo formado por pequenas partículas históricas; o pensamento precisa do passado para que se coloque luz no presente; mas esse movimento é também pendular, pois o presente não é estático, na medida em que ele também lança luzes sobre o passado; as experiências interpretadas à luz dessa concepçáo nos fornecem as "imagens dialéticas em repouso" para pensarmos a velhice na contemporaneidade e seus processos identitários (Benjamin, 2005, p. 465).

Para Benjamin, a experiência está intimamente relacionada à memória. Ela possui o peso da tradição e é passada e repassada entre as geraçóes. Por ter o peso da tradição e por se situar no âmbito da transmissão geracional, o conceito pode ser relacionado ao processo de envelhecer. Se, para Benjamin, a experiência é a transmissão de histórias pela narração, ela sempre será comunicada pelos mais velhos aos mais jovens. A autoridade da velhice está edificada em histórias, às vezes como narrativas, outras como conselhos; enfim, é a capacidade de narrar, de transmitir a experiência, uma experiência que está no espaço e está no tempo. Um espaço-tempo tecido de relaçóes materiais e culturais, que estabelece muitas e diversificadas relaçóes, pois o narrador que já viveu muito é possuidor de uma sabedoria de vida (Benjamin, 2012, p. 123).

O conceito de experiência, ao colocar em xeque a concepção linear de 
conhecimento baseada no continuum da própria história, nos permite desenvolver a crítica de um determinado modelo de razão e de racionalidade quando pensamos a velhice como uma experiência na qual se partilha identidades diversas, que vem sendo expelida do sujeito pelo pensamento moderno. Denominado como a pobreza de experiência, cada vez mais o mundo contemporâneo transforma "os homens antigos em criaturas inteiramente novas [...]. De resto, essas criaturas também falam uma língua inteiramente nova” (Benjamin, 2012, p. 126). Tais processos de transformação criam a incapacidade de narrar, de transmitir experiência. Definida por Benjamin como um sintoma da modernidade, que quer apagar os vestígios, os fragmentos, as sobras do passado que ainda estáo no presente, o pensamento moderno, científico, cada vez menos positiva todo e qualquer vestígio de mistério, de tradição. Para Benjamin, a morte da experiência significa a morte da história, o que caracteriza a tentativa de apagamento de outras histórias, das tradiçôes, por fim é a tentativa de apagamento conformado de tudo que pode ser experimentado pelo sujeito, no caso do nosso estudo, do sujeito velho.

Diante dessa reflexão benjaminiana, as configuraçóes das identidades na velhice como um discurso ideológico quando tentam estabelecer a validade de um determinado imaginário, acabam por desconsiderar a multiplicidade das experiências de envelhecimento. Assim, é preciso cuidar para que o esvaziamento de uma vida rica em significados e sentidos construídos socialmente não seja um padrão. $\mathrm{O}$ idoso precisa ser considerado um narrador, alguém que experienciou e ainda experiencia as transformaçóes que ocorreram ao longo do tempo nas relaçôes entre as pessoas e o mundo que as circundam. Na condição de testemunha de nossa história, as memórias dos velhos, quando reveladas, se tornam uma fonte inesgotável de experiências constituídas por contradiçôes e rupturas que engendram os fragmentos da história de maneira a fazer vir à tona os vestígios do passado. Dessa maneira, ao se construir uma historiografia que reflete sobre a velhice, é preciso ter em mente que os cacos da história, postas nas narrativas dos velhos, nos permite um discurso múltiplo, marcado necessariamente por uma escrita não didática, mas uma possibilidade polifônica e não linear de conhecimento; por isso sempre fragmentária e inconclusa, como é a história.

\section{0 testemunho de uma experiência sobre a velhice}

Neste contar dialético, a história precisa ser pensada de maneira que produza a desterritorialização, a interrupção, a descontinuidade nesse estável imaginário que se tem sobre o envelhecimento, pois que esse processo nos apresenta uma realidade que se constitui como multiplicidade e, como tal, não está contida em nenhuma totalidade. Nesse sentido, as identidades nos processos de envelhecimento necessitam ser percebidas 
como algo em permanente construçáo, uma obra inacabada - aberta - que possui direçóes movediças, desconexas e não é imutável. Portanto, sua compreensão não pode ser estabelecida de modo linear; é preciso pensar a velhice a partir de lugares diferentes, por meio dos vestígios, dos fragmentos reconfigurados pela memória; é preciso estar ligado a uma constelação de ideias, pois é urgente "escovar a história a contrapelo", por meio de um olhar atento às transformaçôes históricas da percepçấo humana, pois a velhice é um campo de estudo atravessado por diversas forças, saberes e práticas contemporâneas que não pode ser determinado a partir de um certo modo considerado como correto de envelhecer. Portanto, não se trata apenas de buscar uma reflexão interdisciplinar ou uma troca entre territorialidades postas pelos discursos científicos, mas é preciso estar atento à perspectiva que comporta uma fusão dos saberes, sem hierarquias ou justaposiçóes. Assim, ao sair dos eixos disciplinares, o caminho que se propóe aqui é o da direção contrária à esperada. Interessa-nos aquilo que foi esquecido pela história, ou simplesmente o discurso ignorado pelo racionalismo, por isso a opção aqui é compreender as identidades na velhice a partir do relato de uma narradora, uma senhora de 71 anos de idade.

Ana Maria Modesto, dentre tantas outras mulheres possíveis, foi a escolhida para nos dar seu testemunho sobre suas experiências vividas ao longo de mais de sete décadas, uma mulher que viveu metade do século XX e todo o século XXI, viveu a ditadura militar, lutou na guerrilha urbana, empunhou faixas a favor das Diretas, viu a redemocratização como consolidaçáo da democracia, sonhou e continua sonhando com a consolidação das instituições democráticas, mesmo neste momento de pandemia se mantém consciente da necessidade de luta constante para a construção da democracia. Filiada ao Partido dos Trabalhadores (PT), participa dos movimentos, conforme ela mesma nomeia, de "resistência aos desmandos governamentais". A escolha dessa narradora se deu porque, além de ser uma mulher extremamente ativa no alto de seus 71 anos, desde 2013 figura como uma das narradoras de um projeto de pesquisa sobre a guerrilha urbana no eixo Brasília/Goiânia que desenvolvo no âmbito da Universidade de Brasília (UnB). Ana Maria foi militante da organizaçáo Vanguarda Armada Revolucionária Palmares (VAR-Palmares), foi presa, mas não sofreu tortura física.

As conversas feitas com essa narradora em sua casa no dia 13 de fevereiro de 2021, com duração de duas horas, foram iniciadas tratando sobre a temática da velhice. Não foi estabelecido um roteiro prévio. No decorrer do depoimento, a fala foi perpassada por temas referentes à saudade, ao amor, à luta política, entre outros temas suscitados tanto pela pesquisadora, quanto pela narradora. Ressalta-se que cada entrevista feita com ela neste projeto de pesquisa tem se revelado importante, por ser diferente de todas as outras (Portelli, 1997). É por meio da história oral, metodologia a qual recorro nesta pesquisa, que está sendo possível "devolver" a Ana Maria suas experiências, as suas memórias que fazem da sua narrativa a possibilidade de vivenciar 
a sua história, um lugar fundamental para a sua compreensão como sujeito, na qual suas identidades emergem "mediante suas próprias palavras" (Thompson, 1992, p. 22). A escolha da história oral como forma de acesso às narrativas pessoais nos possibilita pensar as memórias compartilhadas como um locus privilegiado para que a experiência dos processos de envelhecimento surja derivada de uma percepçáo subjetiva, uma subjetividade que subjaz aos relampejos de memória, que na junção dos cacos, dos fragmentos, ressignificam imaginários e representaçóes sacramentadas sobre o idoso ou a idosa. Mais do que uma narrativa comum de fatos ocorridos, a história oral permite, por meio de conversas partilhadas entre aquele que narra e aquele que ouve, vivenciar as experiências diluídas em memórias individuais e coletivas de forma a compreender o impacto dessas experiências no âmbito do mundo individual e social (Portelli, 1997).

O registro da experiência da nossa narradora se coloca como memória construída diante de uma consciência do presente que se institui. As experiências reveladas por meio da fala colocam em fulcro as vivências cotidianas experimentadas em distintos lugares de fala: mulher, mãe, avó, idosa, militante... Cada palavra proferida é a materialização de uma história vivida e sentida. Ao redefinir o conceito de verdade e recuperar a linguagem como campo para a ressignificação do sujeito e da história, a história oral nos apresenta caminhos que levam a um diálogo entre o conhecimento, o reconhecimento e que é definido como verdade; a sensibilidade e o entendimento, a memória e a história, a experiência e a narrativa. A história oral reivindica outra forma de expor a verdade. A perspectiva posta por esta metodologia requer que a crítica ao que definimos como conhecimento empírico do real questione os limites rígidos da racionalidade técnica científica, na medida em que preconiza um tipo de conhecimento que inclui as paixões e as utopias indispensáveis à vida, sem as quais não há humanidade possível. As metáforas, as imagens, os símbolos intrínsecos ao ato de narrar, constroem uma visão de mundo que não é, certamente, aquela do pensamento sistemático, limitado a verdades conclusivas. Ao contrário, trata-se de uma metodologia que amplia as possibilidades da escrita científica, porque se move nas rugosidades do discurso que se refazem como imaginários nos fluxos de memória e definem identidades. Para Bobbio, ao se ocupar do passado, ao repensar suas experiências, a pessoa idosa reconstrói sua identidade, pois:

O tempo do velho [...] é o passado. E o passado revive na memória. O grande patrimônio do velho está no mundo maravilhoso da memória, fonte inesgotável de reflexóes sobre nós mesmos, sobre o universo em que vivemos, sobre as pessoas e os acontecimentos que, ao longo do caminho, atraíram nossa atenção [...]. Esse imenso tesouro submerso jaz à espera de ser trazido à superfície durante uma conversa ou uma leitura; ou quando nós mesmos vamos à sua procura nas horas de insônia; outras vezes surge de repente por uma associação involuntária, por um movimento secreto da mente. Se o mundo do futuro se abre para a imaginação, mas não nos pertence mais, o mundo do passado é aquele no qual, recorrendo a 
nossas lembranças, podemos buscar refúgio dentro de nós mesmos, debruçar-nos sobre nós mesmos e nele reconstruir nossa identidade. (Bobbio, 1997, p. 53).

E é nesses fluxos de memória que a nossa narradora define sua identidade como idosa.

Normalmente a gente pensa o velho como uma pessoa triste, uma pessoa rabugenta, uma pessoa que fica quieta num lugar e embirra. Isso eu senti num grupo de uma escola, [quer dizer] não era uma escola. Fiz um curso sobre como envelhecer na UnB [Universidade de Brasília] e eu sentia que todas as alunas lá, [principalmente] as mais velhas, ficavam embirradas. 'Ah, eu não vou mudar para ali, não, minha filha quer que eu vou para ali, e eu não vou. Isso eu não faço, aquilo ali eu não faço'. Eu senti que tem muito isso no velho, e eu saio desse parâmetro, que eu quero é mudar cada dia mais, um dia num lugar, outro dia noutro lugar. Se tiver que morar com filho, eu moro; se não tiver, não moro. É assim, não quero ficar rabugenta, eu quero sempre viver, sentir, fazer coisas. Então eu percebi que o velho no Brasil não sei o porquê - muitos tem essa coisa de não querer fazer as coisas, de embirrar, de ficar triste, de não querer mudar de lugar. Não quer nada, [o velho] quer ficar emburrado, brigando com filho, brigando com filha, Deus que me livre de ficar assim, aí acho que a vida fica muito sem graça, né? Mas se ele quer também é um direito dele! (Ana Maria Modesto, 2021).

Na fala, observarmos que o processo de envelhecimento sob a ótica da depoente está associado a duas dimensōes identitárias; em uma identificamos o idoso com condutas, hábitos, crenças e imagens que ratificam concepçôes tradicionalmente associadas às etapas mais tardias da vida, em que se articulam representaçôes do envelhecimento com a rabugice, ao descanso, a quietude e a inatividade; a outra dimensão, com a qual ela se define, contrapóe esse modelo e sugere a existência de uma definiçáo vinculada ao estímulo à atividade, à aprendizagem, à flexibilidade. Essa variaçáo das experiências culturais salientadas na narrativa sobre o envelhecimento está subjacente à identidade do idoso. Na sua fala, Ana não generaliza as diferentes experiências da velhice, para ela tais experiências não estão resumidas a um padrão determinado, pois há os velhos "embirrados" e os que mudam quando é preciso mudar. Ao não resumir as identidades sob um único conjunto de características para aquele que é velho, percebemos que na contemporaneidade é possível identidades diversas na velhice, não há uma limitação para o processo de envelhecimento.

Para alguns estudiosos, os sujeitos que estáo vivenciando hoje a experiência contemporânea da velhice são de uma geraçấo específica, um grupo de pessoas que nasceram após a Segunda Guerra Mundial. Com características próprias, essa geração experiencia um processo de envelhecimento próprio. Chris Gilleard e Paul Higgs (2002) afirmam que o caráter geracional desse grupo específico é o fator preponderante para a definição das características desta identidade experimentada por Ana Maria. Os 
autores partem da proposta de Laslett de conceber esse momento da vida (designado como terceira idade) a partir da emergência de novas identidades. Terceira idade, ainda que seja um termo controverso para alguns pesquisadores, para outros o debate que se coloca é que ele acrescenta outras possibilidades para a descriçáo e compreensão das possíveis maneiras de se envelhecer, pois concede aos sujeitos a possibilidade de atribuição de significados subjetivados pelas experiências narradas e sentidas por aquele que desfruta o envelhecimento na contemporaneidade. A terceira idade lança luz sobre o corpo que envelhece e exige dele um arsenal de técnicas de autoconhecimento, autorregulação, autocontrole e vigília de si. A subjetivação dos regimes de verdade que tomam o envelhecimento a partir da perspectiva da terceira idade como marcador regulatório na produção dos sujeitos dá contornos às subjetividades e a uma aparente interioridade subjetiva de maneira a moldar discursos que regulam modos ditos legítimos de existir a partir de demarcaçôes bem delimitadas. Essa dimensão semântica dada pelo conceito de terceira idade pode estar encarnada nas palavras que definem os processos de envelhecimento relacionados às questóes identitárias no tempo presente. A partir do termo, talvez possamos experimentar um tipo de conhecimento diferente daquele que encontramos no pensamento científico, empírico e técnico. Quando se pensa sob a perspectiva benjaminiana, percebe-se ser a linguagem portadora de um devir da verdade, assim o conceito de terceira idade pode ser um devir (ou desvio) o qual nos fornece imagens alegóricas e fragmentárias de representaçóes postas nas memórias de Ana, o que não constitui uma manifestação de irracionalismo, mas uma forma de falar do mundo. Daí o interesse pelas experiências da nossa entrevistada materializadas tanto nas memórias como nas narrativas por ela engendradas em seus atos de fala que, ao serem tomados como referência para a compreensão da velhice, mostram que a experiência da narradora diante de um mundo imaginário, muitos vezes naturalizado em representaçóes reificadas, assume uma dimensão ética oposta a do esteticismo e do ceticismo de compreensóes que não singularizam a experiência dentro de uma dimensão histórica localizada em tempos e espaços próprios. De maneira geral, é importante salientar ser a questão da velhice um campo de discussão, no qual questóes sobre corpo, família, solidão, qualidade de vida, saúde, espaços público e privado, morte e finitude engendram o olhar contemporâneo para a velhice a partir de uma sobreposição de saberes e visóes definidoras do objeto "velho" e, por consequência, da própria noção de envelhecimento. Tal perspectiva tende a variar entre um cientificismo, uma moralidade do corpo e uma racionalidade de controle, que foram produzidas a partir de diversos enunciados sobre a velhice e sobre o envelhecimento. Esta tensão entre esses discursos se revela pela forma como alguns enunciados sobre a velhice ora a colocam como uma fase dramática da vida, ora exaltam esse momento como o tempo do descanso do trabalho, de desfrute dos prazeres que náo se pôde ter durante a vida. Tais discursos se inserem na contemporaneidade por meio dos deslocamentos históricos em relação às formas de se representar a velhice, ora como uma denúncia do corpo como obstáculo, prisão e lugar de alienação, ora a partir da exaltação do mesmo, como espaço de prazer, 
como meio de liberação individual e coletiva.

Para Chris Gilleard e Paul Higgs (2002), essa nova identidade se coloca a partir tanto de uma definição conceitual quanto como explicaçáo descritiva das experiências vividas pelo sujeito. Diante da necessidade de explicaçáo e apropriação da questão geracional como possibilidade de entendimento das condiçôes de envelhecimento que fez emergir para os estudiosos o termo "terceira idade", os autores se utilizam de três categorias, quais sejam: classe, grupo de nascimento e geraçáo. Para explicar a opção pela questâo geracional como categoria explicativa, os mesmos ressaltam a incompletude das categorias classe e grupo de nascimento.

Segundo tais autores, a categoria classe, embora nos permita entender como os estilos de vida adotados na velhice possibilitam ao idoso experimentar condiçóes em que acessam saúde, lazer e mais segurança, ela não nos permite afirmar que a identidade seria determinada unicamente por esse valor, pois há idosos que, mesmo tendo uma situação financeira confortável, ainda são "imbirrentos" e ratificam o viver a velhice como um momento de imobilidade de independência. Uma percepção que encontramos no trecho anteriormente citado da narrativa.

$\mathrm{Na}$ fala, anteriormente citada, da narradora, é possível observar convergências com os pensamentos dos autores, pois a adoçáo de estilos de vida e de sistemas de crenças, embora possam influenciar, não estabelecem uma relação direta com a classe social como uma característica distintiva da identidade. Pensar uma explicaçáo para a identidade do idoso requer outras dimensóes do conhecimento. No esforço de compreensão do processo de envelhecimento surge a categoria grupo de nascimento, uma categoria que se junta a outro conceito para pensar a velhice designada como terceira idade. Ao utilizar a categoria nascimento considera-se a experiência da velhice como uma experiência de um grupo de pessoas privilegiadas. Poderíamos pensar a identidade da nossa narradora a partir dessa definição? Embora não seja complicado pensar uma delimitação dos diversos grupos de nascimento, aqueles que nasceram após a Segunda Guerra Mundial - como é o caso de Ana Maria - fariam parte de uma geração que acessa mais recursos financeiros, maior qualidade de vida e maior independência cultural, política e econômica. Embora a importância sociocultural deste grupo ressignifique a compreensão da terceira idade, essa categoria "grupo de nascimento" náo nos permite compreender as transformaçóes culturais vivenciadas pela sociedade após os anos de 1950, as quais sem dúvida alguma influenciam no presente a definição do que seja ser velho.

O envelhecimento para que seja compreendido enquanto fenômeno múltiplo e complexo náo está alheio a um conjunto de determinantes de ordem subjetiva, cultural, econômica, social e política. Assim é mister compreender esses determinantes na construção das relaçôes as quais se circunscrevem a terceira idade de maneira a desconstruir a naturalização do envelhecimento sob a imposição dessa nova imagem da velhice dada pelo grupo de nascimento e pela classe. Dessa maneira, é preciso 
buscar outras categorias que nos revelem as práticas de poder e formaçóes de saberes em torno das questôes que legitimam a compreensăo desse amálgama que se institui em uma correlação de forças que expóem contradiçóes engendradas pelo conhecimento e explicação dos processos de envelhecer. Problematizar o processo de envelhecimento requer reconsiderar o lugar que destinamos a cada geração e as transformaçóes sociais e culturais alocadas no tempo e no espaço. Isso posto, é possível verificar que as mudanças aceleradas vividas pela sociedade do pós-guerra responderam pela transformação de uma geração, uma categoria que se junta à categoria grupo de nascimento, considerada importante para compreendermos a experiência da terceira idade (Gilleard; Higgs, 2002). Nesse sentido, a velhice de um grupo de nascimento se situa como lugar privilegiado de testemunho e de experiência narrativa da história de toda uma geração que experimentou as transformaçóes culturais a partir da segunda metade do século XX. Gilleard e Higgs (2002) buscam em Karl Mannheim o conceito de geraçáo para compreender a denominação da velhice como viver uma terceira idade. Para Mannheim (1982), uma geração significa o compartilhamento de localização temporal, histórica e sociocultural. Para o sociólogo, não basta haver nascido em uma mesma época, ser jovem, adulto ou velho nesse período náo significa uma experiência geracional. $\mathrm{O}$ que caracteriza uma posição comum de quem nasce em um mesmo tempo cronológico é a potencialidade e a possibilidade que se coloca para os indivíduos de presenciar e vivenciar determinadas experiências comuns, participar dos mesmos acontecimentos, e, sobretudo, de compreender e conhecer esses acontecimentos ou experiências de forma semelhante. Embora as transformaçôes socioculturais do pósguerra com a possibilidade dada pelos meios de comunicação ampliem as possibilidades de participação das pessoas em diferentes partes do globo em um conjunto de acontecimentos e experiências semelhantes colocando-os em uma mesma posição geracional, isso não significa necessariamente uma identificação geracional comum, pois que a experiência geracional implica necessariamente em formas semelhantes de ordenação e estratificação dessas experiências pelos indivíduos do grupo de nascimento.

A geração da qual faz parte a nossa narradora, que envelhece no início do século XXI, experimenta a possibilidade de vivenciar a terceira idade influenciada por uma série de condicionantes históricos que favorecem um processo de envelhecer marcado por identidades que contestam paradigmas, desnaturalizam imaginários e recriam representaçóes. Essa geração foi exposta a determinadas condiçôes históricas que as tornaram um grupo social que, além de consumir bens e serviços, viveram uma experiência cultural que abarcou as esferas públicas e privadas do mundo social. As identidades dos sujeitos passam a ser determinadas pela a política, pela cultura, pela economia, enfim, os comportamentos expressam marcas distintivas de maneira a criar novos hábitos, revolucionar costumes, imprimiram e vem imprimindo mudanças nas formas de pensar a vida, de pensar e repensar a velhice.

Envelhecer é uma coisa assim [...]. É difícil. Eu acho que a pele da gente vai ficando 
enrugada, então a gente envelhece mesmo, é de verdade. Mas a cabeça parece que não envelhece, então fica assim: a gente olha o corpo, velho, e a cabeça, não, ainda parece que eu sou aquela jovem cheia de esperanças que queria mudar o mundo lá nos ano sessenta. Fica meio estranho, eu estou nesse ponto, que eu acho muito estranho, sinto [isso]. (Ana Maria Modesto, 2021).

Como nos coloca a fala de Ana, sua cabeça ainda está marcada por uma poderosa cultura jovem. Em nossa sociedade, normalmente associamos a velhice às modificaçóes no corpo, as rugas são um exemplo de marcas desta distinção. Segundo (Barreto, 1992, p. 26) as marcas da velhice expressas no corpo são características que não se pode esconder. $\mathrm{O}$ espanto da nossa narradora diante do corpo envelhecendo associa-se ao que o autor denomina como o envelhecimento social, pois a vida social, muitas vezes, não abdica de mostrar ao velho a proximidade da morte com a transformação do corpo.

Às vezes eu falo: meu Deus, mas eu estou velha já, mas não estou velha, [pois] eu quero dançar, eu quero ainda sair, eu quero viajar muito, e [eu quero] muita luta, penso que ainda vou lutar muito, apesar de querer mudar. Mas eu luto em outro país. Se não puder mudar, eu vou ter que ficar aqui mesmo e lutar, porque eu preciso da democracia e sei que ela precisa de mim, sem democracia não dá, né? (Ana Maria Modesto, 2021).

Essa fase de transição para a velhice se coloca em um jogo de memórias que parece sempre conversar com a ativista política dos anos de 1960. A fala revela esse ativismo político de oposição ao governo denominado por ela como fascista e reflete agora, no momento do envelhecimento, um comportamento considerado típico da geração da qual faz parte. $\mathrm{O}$ fato de uma mulher de 71 anos ainda querer lutar pela democracia, como fez na arena política nos anos de 1960, é herança de um momento vivido por alguns homens e algumas mulheres nascidos nos meados do século XX, signatários de um comportamento que foi possível surgir na esfera pública naquele período, o que não significa que todos os velhos de hoje nascidos naquele período compartilhem dessa mesma perspectiva. Percebe-se que Ana compartilha características comportamentais no que tange ao desejo de transformação que interfere consideravelmente na construção das suas identidades. Essa influência sobre a formaçáo da identidade da terceira idade nos permite observar que algumas pessoas que compartilharem a revolução dos costumes, como é o caso da nossa narradora, que não se resignou a definição do papel da mulher na década de 1960, contestaram os papéis de gênero e se apropriaram do exercício da política, invadindo a arena até então considerada apenas masculina. Hoje, beneficiadas pelos avanços na expectativa de vida, experimentam formas singulares de agir e sentir que contestam as representaçóes que associam a velhice a um momento de inoperância, de sobrecarga, de doença; ela busca repetir e atuar de forma transformadora na velhice, 
assim como fez quando jovem, no mundo social.

Embora tenha consciência de que as formas de luta hoje são distintas, pois a velhice passa a ser vivida a partir de uma perspectiva da potência da velhice conduzida pelos ideais contemporâneos que regulam os modos de ser dos velhos, a fala de Ana tende a uma maximização da potência do velho, na qual ao realçar o desejo de lutar, de dançar, de viajar, ela quer, de alguma maneira, negar a finitude do corpo velho criando a ilusão de uma materialidade passível de ser alcançada a partir da tentativa de recuperar suas lutas da juventude, de viajar, de dançar...

$\mathrm{Na}$ pandemia eu só fiquei com os grupos. Por exemplo, nosso grupo de 'Lula Livre', formado por pessoas mais velhas, muitas mulheres assim como eu, que era às quartas-feiras. Toda quarta-feira a gente ia, eu e minhas amigas, eram mais mulheres, né? E agora eles começaram de novo, [mas toda quarta-feira a gente] ia lá para o Supremo [Tribunal Federal] para pedir 'Lula Livre'. Então isso parou, mas eu tenho contato com o grupo. O grupo vai, vejo as fotos, eu ajudo financeiramente às vezes, um pouquinho, com dinheiro. E continuam esses grupos, a gente continua lutando, nós temos que continuar insistindo na luta política, não tem outro jeito! Mulher tem que ir pra rua, nós fomos quando era mais difícil a mulher ir, imagina agora que a gente pode ir sem ser escondido? E continuam esses grupos [...] são eles que me dão esperança, que me deixam sonhar ainda, porque tá difícil, não tá fácil não. Tem esses grupos que me alimentam na política, que me alimentam muito. (Ana Maria Modesto, 2021).

$\mathrm{Na}$ sua fala, quando faz referência a pandemia, Ana se refere diretamente às mudanças das rotinas. Para ela o que ficou foi a saudade do tempo dos encontros, mas ela deixa clara a compreensão da necessidade de se recolher, pois "não há outro jeito”. Não é possível depreender na narrativa as manifestações psicológicas vivenciadas por muitos velhos, pois como ela mesma afirma, para ela a alteração foi os encontros e a saudade de abraçar os netos. A chegada dessa geração a qual Ana se vincula à velhice nos apresenta outras possibilidades de se experienciar esse momento da vida. Para Gilleard e Higgs (2002), essa geração carrega uma espécie de herança cultural dos anos de 1960 que impacta as identidades emergentes da chamada terceira idade. Por trazer consigo uma consciência intergeracional, é cada vez maior o número de idosos como Ana que querem dançar, viajar e continuar ocupando a arena pública para o exercício da política. Percebe-se uma perspectiva comportamental vivida por essa geração associada a comportamentos comumente designados aos sujeitos que ainda náo são classificados como parte da terceira idade, como ela mesma afirma quando nos diz que "a gente olha o corpo, velho, e a cabeça, não, ainda parece que eu sou aquela jovem cheia de esperanças que queria mudar o mundo lá nos ano sessenta... meu Deus, mas eu estou velha já, mas não estou velha”. Para os autores, a identidade da terceira idade é resultado de uma consciência geracional, de modo que as características da 
identidade da terceira idade podem ser tributárias, em grande parte, do caráter inovador próprio à geração. Porém, é preciso nos atentar que reduzir a identidade à expressão da consciência geracional desses sujeitos, pode significar a expulsão e a desvalorizaçáo da experiência etária daqueles que hoje são idosos e não compartilham as experiências dessa geração, mesmo sendo do mesmo grupo de nascimento, também reconhecidos pela narradora quando nos fala da sua turma do curso sobre envelhecimento feito por ela na Universidade de Brasília que eram embirrados, rabugentos e náo queriam ser de outra forma. Embora seja uma categoria relevante, no que se refere a sua definição, a sua relevância cultural, a sua capacidade de formar novas experiências subjetivas e o caráter amplo que vem adquirindo na contemporaneidade, o aspecto geracional da experiência da terceira idade pode conferir características particulares a alguns sujeitos e sujeitas que experimentam a velhice no momento atual. Nessa ordem de pensamento, cumpre-nos entender a terceira idade como a vivência específica desses sujeitos, pois seria demasiadamente perigoso classificar os modos de vida desse grupo como uma experiência cultural inovadora e possível de ser expandida para todas as possibilidades de compreensão das identidades dos velhos. Alguns autores alertam ainda que ao pensar a velhice a partir da categoria terceira idade, corre-se o risco de homogeneizar um grupo populacional que internamente é bastante complexo no que se refere as diversidades de experiências em relaçáo ao envelhecimento, posto que as dimensóes sociais como o gênero, classe social, raça/etnia e orientação sexual constituem-se importantes linhas de subjetivação as quais não podem ser abandonadas quando se analisa a heterogeneidade das experiências de envelhecimento.

Dessa maneira, categorias como classe, grupo de nascimento e geração acrescentam informações à compreensão de forma que, quando interseccionadas, nos ajudam a refletir sobre as condiçóes que vêm marcando a experiência de envelhecer na contemporaneidade, bem como sobre as injunçóes a que os sujeitos inseridos nesse processo vêm se submetendo no âmbito das perspectivas culturais vividas em contextos sociais diversos.

'Gente, a gente tem de sair para a rua, tem de fazer'. Mas como? Aí, eu não posso sair para a rua. 'Vamos sair, vamos para a rua?' Tem que ir pra rua lutar, fazer um monte de coisa que a gente tinha de fazer nesse governo. Ah, eu misturo tudo. Eu sou eu, eu sou aquela lá de 1960, é isto. O que eu sinto falta? Eu sinto mais falta mesmo é da luta, de poder ir pra rua, de poder pelo menos estar fazendo alguma coisa para mudar tudo isto: esse governo, essa coisa que nem governo é, esse fascismo, essa coisa maluca. 'Luta mesmo, tem que lutar'. Aquela luta que a gente fez - 'A Petrobrás é nossa!' Olha o que a gente falava - 'Fora imperialismo!' Olha, a nossa luta era essa. Hoje, nós não temos Petrobrás, o americano [está] mandando aqui. (Ana Maria Modesto, 2021).

Conforme Ecléa Bosi (2003), a memória dos idosos é responsável por 
mediar as experiências da geração atual e aquelas vividas no passado; através dessas memórias temos a possibilidade de outros regimes de verdade, de outras maneiras de conhecimento e reconhecimento de subjetividades silenciadas. Quando nossa narradora diz que "a nossa luta era essa, olha a nossa luta" é possível perceber nos seus atos de fala apropriaçôes das paixões e das sensaçóes expressas nas frases proferidas, o que nos permite constatar as intensidades e a maneira como ela vive e viveu o acontecimento narrado. A multiplicidade de discursos e de complexidade histórica refletidas na fala de Ana aponta para uma dimensão política e teórica na composição da produção discursiva sobre velhice.

Os discursos e os enunciados que significam a velhice e que constituem os sujeitos velhos se colocam pelas experiências articuladas a partir da correlaçáo entre campos de saber e formas de subjetividade, pois como afirma Joan Scott, "não são os indivíduos que têm experiência, mas os sujeitos é que são constituídos através da experiência" (Scott. 1999, p. 27). Dessa maneira, as singularidades das experiências vividas por Ana na sua constituição como sujeito se alicerça em uma contingência histórica em que a produção dos sentidos e significados dessas experiências estão atreladas a um tempo e espaço históricos, seja nos modos de sujeição, seja nas formas de resistência e na própria relação que ela estabelece consigo mesma nas suas digressóes narrativas.

Para além de um padrão unilateral das experiências, o que se observa são os pontos de vista marcados por uma linguagem que enriquece e contradiz certezas de vários pontos de vistas contraditórios (Bosi, 2003). Assim, o discurso de Ana deve ser compreendido como um fenômeno que se realiza nela própria, como ontogênese do sujeito, ou seja, como caminhada do ser em um processo infindável em que, conforme ela mesma afirma, "Eu sou eu, eu sou aquela lá de 1960". Dessa maneira, como agente transformadora dos espaços com os quais interage e atribui significados, as suas experiências é que manipulam os inúmeros papéis que representam essas mulheres, a jovem e a velha, que habitam um mesmo corpo. Por isso, ela firma que:

Não quer nada, [o velho] quer ficar emburrado, brigando com filho, brigando com filha, Deus que me livre de ficar assim, aí acho que a vida fica muito sem graça, né? Mas se ele quer também é um direito dele! Náo percebe que a gente tem que brigar é por políticas públicas para a gente ser feliz, para o velho poder andar, poder ir ao cinema, ter ônibus, ter acessibilidade para ir a outros lugares, [para] entrar num ônibus e viajar sozinho; saúde também para o idoso, para o velho. Por isso que eu não descanso de lutar! A vida é esta luta constante, ela não permite acomodaçáo, ainda mais agora. Se a gente quer o idoso vivendo com qualidade, esta pandemia mostrou que não podemos ficar em casa esperando a morte e implicando com filho, a gente tem que sair, a gente tem que mostrar o que nós queremos, nós estamos vivos, nós pensamos, nós produzimos, de forma diferente dos jovens, mas a gente é parte desse país. As nossas experiências são importantes, ela pode ensinar muita gente a fazer coisas novas, a repetir coisas boas que a gente viveu. (Ana Maria 
Modesto, 2021).

Nas palavras de Ana é possível verificar que ela proclama a forma de envelhecer a partir de uma potência que se coloca na capacidade de ação do idoso. Embora tenhamos potências que proclamam uma perspectiva, a sua potência de agir quer desenhar uma outra arquitetura para um outro mundo, distinto da história dos seus pares, da pessoa que "Náo quer nada, [o velho] quer ficar emburrado, brigando com filho, brigando com filha, Deus que me livre de ficar assim, aí acho que a vida fica muito sem graça, né?”. Para ela, a luta por políticas públicas que valorizem as experiências dos velhos é muito mais do que a vontade de consumir bens e serviços, em verdade trata-se de uma postura moral que tem como perspectiva os valores superiores da vida, que na sua fala aparecem como um bem e um dever a ser conquistado. Assim, a luta contínua empreendida pelos sujeitos na velhice é uma forma de mostrar que "As nossas experiências são importantes, elas podem ensinar muita gente a fazer coisas novas, a repetir coisas boas que a gente viveu”. Mais do que uma possibilidade de reintegrar a experiência aos corpos coletivos e individuais, a fala de Ana aparece como uma força disruptiva que não pode ser considerada como mero instrumento de elaboraçáo dos dados da realidade nem como simples abstraçáo, mas é pensada como campo no qual emerge uma intrincada rede de relaçôes entre memória e história em que o conhecimento não se separa do imaginário e do pensamento.

A partir dos relatos de nossa narradora, percebe-se que na contemporaneidade pensar e produzir significados para a velhice ultrapassa ou ao menos resiste às modulaçóes normativas como forma de enfrentamento à massificação e à serialização das subjetividades. Assim, problematizar as experiências da velhice para além de perspectivas homogeneizadoras é entender que os corpos velhos carregam consigo as singularidades de vivências nas complexidades e nos imbricamentos das forças sociais, políticas e históricas que produzem os processos de envelhecimento e os sujeitos velhos. A partir do acolhimento da possibilidade de se conhecer os processos identitários nos processos de envelhecimentos, nos quais os idosos se reconhecem, é possível colher evidências que mostram as articulaçóes e rupturas engendradas com as problematizações constituídas com base nas conexôes existentes entre memória e experiência e suas relações com o campo dos estudos históricos sobre o velho.

\section{Considerações finais}

A importância da compreensão da velhice como experiência narrativa se justifica nas histórias de vida guardadas na memória dos velhos, memórias estas que constroem uma narratividade que ao serem recordadas estabelecem um sentido de continuidade cultural 
entre as geraçóes. Através das recordaçóes das pessoas idosas, é possível percebermos transformações ocorridas no espaço, na história, nas instituiçóes, nos papéis sociais e no imaginário social conforme nos ensina Ecléa Bosi (2003). Através de lembranças atualizadas e reatualizadas nas relaçóes entre um passado que se torna presente por meio das lembranças, as experiências do idoso se constituem como instrumento indispensável nas relaçóes intergeracionais. Se, como afirma Bobbio (1997), o grande patrimônio da pessoa idosa está no universo da memória social, essas memórias, ao materializar as experiências vividas e sentidas, se tornam possibilidades de reflexóes sobre o mudo social.

Ao procurar conhecer a história do envelhecimento por meio da história oral, é possível identificarmos as transformaçóes vivenciadas dentro dos processos singulares do envelhecimento. À medida que acessamos as subjetividades do idoso, suas expectativas, seus desejos, suas paixôes, além de nos ocuparmos de contexto social histórico, também nos ocupamos do passado, de modo que podemos repensar experiências e identidades ratificadas por sistemas de representaçóes que afirmam outras identidades possíveis àquele que envelhece. Nessa medida, por meio da história oral, a pessoa idosa quando fala ela também reconstrói a imagem de si, nessa interação permanente entre o vivido e o aprendido; em processos de rememoração as identidades se refazem, pois "o que está em jogo na memória é também o sentido de identidade individual e de grupo”, (Pollak, 1989, p. 9).

Dessa maneira, o relato individual aqui analisado tem um importante papel social na medida em que cada um dos atos, cada sonho lembrado, cada desejo de comportamento reverbera um sistema social no qual está contida por inteiro a história da vida individual da nossa narradora, pois cada indivíduo é a reapropriação singular do universo social e histórico que o rodeia. Conforme Ferraroti (1988), podemos conhecer o social a partir da práxis individual; Todo o ato individual é uma totalização sintética de um sistema social (Ferraroti, 1988 p. 26-27). Dessa maneira, através de suas "histórias", Ana Maria se inscreve socialmente, ela conta a sua história na qual procura evidenciar a sua personalidade política nas dimensóes social, cultural e econômica (Meihy; Holanda, 2013). Se as memórias quando emergem não podem ser silenciadas, pois elas vêm à tona para transformar a história, é preciso estar sempre atento para a necessidade de apropriação, bem como não esquecer a função social como possibilidade de reverberaçáo da cultura, da qual aquele que lembra é portador. Assim, criar situaçóes nas quais essas memórias sejam relembradas, ressignificadas e contadas, é possibilitar a reintegraçáo do sujeito as suas experiências, outrora expulsas pela racionalidade moderna.

\section{Referências}

BALTES, Paul B.; SMITH, Jacqui. Novas fronteiras para o futuro do envelhecimento: a velhice 
bem-sucedida do idoso jovem aos dilemas da quarta idade. A Terceira Idade, São Paulo, v. 17, n. 36, p. 7-31, 2006.

BARRETO, Maurício Lima. Admirável mundo velho: velhice, fantasia e realidade social. São Paulo: Ática, 1992.

BEAUVOIR, Simone de. A velhice. Rio de Janeiro: Nova Fronteira, 1970.

BENJAMIN, Walter [1933]. Experiência e pobreza. In: BENJAMIN, Walter. Magia e técnica, arte e política: ensaios sobre literatura e história da cultura. São Paulo. Editora: Brasiliense, 2012. (Obras Escolhidas, v. I). p. 213-240.

BENJAMIN, Walter. Libro de los pasajes. Madrid: Ediciones Akal, 2005.

BOBBIO, Norbert. O tempo da memória: de senectude e outros escritos autobiográficos. Rio de Janeiro: Editora Campus, 1997.

BOSI, Ecléa. O tempo vivo da memória: ensaios de psicologia social. São Paulo: Ateliê Editorial, 2003.

CERVATO, Ana Maria; DERNTL, Alice Moreira; LATORRE, Maria do Rosário Dias de Oliveira; MARUCCI, Maria de Fátima Nunes. Educação nutricional para adultos e idosos: uma experiência positiva em Universidade Aberta para Terceira Idade. Revista de Nutrição, Campinas, v. 18 , n. 1 p. $41-52,2005$.

GUERRA, Cris. Querido Fábio Porchat. 1 vídeo (11 min). Publicado pelo canal Cris Guerra, 2021. Disponível em: https:/www.youtube.com/watch?v=8FbEVSyaRcQ. Acesso em: 12 fev. 2021.

GILLEARD, Chris; HIGGS, Paul. The third age: class, cohort or generation? Ageing \& Society, Cambridge, v. 22, 2002.

KALACHE, Alexandre; VERAS, Renato P.; RAMOS, Luiz Roberto. O envelhecimento da população mundial: um desafio novo. Revista de Saúde Pública, São Paulo, v. 21, n. 3, p. 200210, 1987.

MANNHEIM, Karl. O problema sociológico das gerações. Tradução Cláudio Marcondes. In: FORACCHI, Marialice M. (Org.). Karl Mannheim: Sociologia. São Paulo: Ática, 1982. p. 67-95.

MEIHY, Jose Carlos Sebe B.; HOLANDA, Fabiola. História oral: como fazer, como pensar. 2. ed. São Paulo: Contexto, 2013.

NERI, Anita Liberalesso (Org.). Idosos no Brasil: vivências, desafios e expectativas na terceira idade. São Paulo: Fundação Perseu Abramo, 2007a.

NERI, Anita Liberalesso (Org.). Qualidade de vida na idade madura. 5. ed. Campinas: Papirus, 2003.

NERI, Anita Liberalesso (Org.). Qualidade de vida na velhice: enfoque multidisciplinar. Campinas: Alínea, 2007b.

NERI, Anita Liberalesso. Teorias psicológicas do envelhecimento: percurso histórico e teorias atuais. In: FREITAS, Elizabeth Viana de. et al. (Org.). Tratado de Geriatria e Gerontologia. 2. ed. Rio de Janeiro: Guanabara Koogan, 2006. p. 56-77. 
NERI, Anita Liberalesso; YASSUDA, Mônica Sanches; CACHIONI, Meire (Org.). Velhice bemsucedida: aspectos afetivos e cognitivos. Campinas: Papirus, 2004.

POLLAK, Michael. Memória, esquecimento, silêncio. Estudos Históricos, Rio de Janeiro, v. 2, n. 3, p. 3-15. 1989.

PORTELli, Alessandro. O que faz a história oral diferente. Projeto História, São Paulo, n. 14, p. 25-39, 1997.

SCOTT, Joan. Experiência. In: SILVA, Alcione Leite da; LAGO, Maria Coelho de Souza; RAMOS, Tânia Regina Oliveira (Org.). Falas de gênero. Florianópolis: Mulheres, 1999. p. $21-55$.

THOMPSON, Paul. A voz do passado: história oral. Rio de Janeiro: Paz e terra, 1992.

\section{Fontes Orais}

MODESTO, Ana Maria [71 anos]. [jan. 2021]. Entrevistadora: Eloisa Pereira Barroso. Brasília, DF, 13 jan. 2021.

Recebido em 23/02/2021.

Versão final reapresentada em 25/04/2021.

Aprovado em 28/04/2021.

Fonte de financiamento: nada a declarar.

Conflitos de interesse: nada a declarar. 